\title{
部分補強された在来工法天井の動的加振実験とシミュレーション解析 DYNAMIC TEST ON PARTIALLY REINFORCED CONVENTIONAL CEILINGS AND SIMULATION ANALYSES
}

\author{
半澤徹也*, 田中栄 次*, 鈴木 健司*, 櫻庭 記彦*, 金子美香** \\ Tetsuya HANZAWA, Eiji TANAKA, Kenji SUZUKI, \\ Fumihiko SAKURABA and Mika KANEKO
}

\begin{abstract}
In recent years, the collapse of ceilings due to earthquakes has become a serious problem. The authors have proposed the reinforcing method to improve the aseismic performance of conventional ceilings. The proposed method employs the partial reinforcement only around the braces of ceilings, and can be easily and economically applied. The shaking table tests of the partially reinforced ceilings were carried out to investigate dynamic characteristics. The analytical model of the reinforced ceilings is proposed based on the static cyclic loading tests and the simulation analyses were carried out to show the effectiveness of the analytical model.
\end{abstract}

Keywords : Nonstructural component, Ceiling, Dynamic test, Simulation analysis 非構造部材，天井，加振実験，シミュレーション解析

\section{1. はじめに}

近年の建築物の地震被害では，非構造部材，特に天井の被害が顕 在化してきており, その耐震性の向上に向けた対応が急がれている。

本論で対象とする軽量鉄骨下地天井 ${ }^{1)}$ の耐震性に関しては, 地震被 害に関する研究2) 4), 部分天井に対寸る実験的研究5) 8), 接合要素 (金 物) に対する実験的研究9) 11), 解析的研究 12) 14)などが行われている。 既往の研究によれば, 天井ボード崩落の被害では, 天井ボードは野 縁とともに落下しており, 崩落跡には多くのクリップの散乱が見ら れること ${ }^{4), 9)}$, クリップの外れは, 鈆直方向の力だけではなく水平方 向の滑動によって, 特に腹掛けクリップの場合に生じ易いこと泉など が明らかにされている。また，平成25年に公布された国土交通省告 示第771号では, 特定天井に対する構造耐力上安全な構造方法を定め ており, 天井設計のための解析技術と解析的研究は今後重要性を増 すものと思われる。

筆者らは，在来の鋼製下地天井の耐震性の向上を図る補強工法と して, ブレース周りの金物の部分的な補強による方法を提案し, $28 \mathrm{~m}^{2}$ 規模の天井システムの加振実験により，その性能を検証した ${ }^{15}$ 。本論 では，この補強工法に改良を加えた天井システムの加振実験を追加 すると共に, 解析モデルによるシミュレーション解析を実施して, その妥当性を検証する。なお, 解析モデルで用いた要素の荷重変形
関係は, 別途実施した $2 \mathrm{~m}^{2}$ 規模の天井試験体に対する静的繰返し加 力実験注 1)結果に基づいている。

\section{2. 動的加振実験}

\section{1 実験計画}

試験体の概要とブレース下端の詳細を図 1 に, 使用部材を表 1 と 写真 1 に各々示す。天井ボードは 2 枚張りで, 野縁・野縁受けから なる下地材にビス止めされている。野縁と野縁受けを含めた単位質 量は $16.5 \mathrm{~kg} / \mathrm{m}^{2}$, 全面積の質量は $462 \mathrm{~kg}$ である。中央部に 1 対のブレ 一スを $\mathrm{V}$ 字形に配置し, その周辺 9 箇所のクリップおよび八ンガー を耐震仕様としている。ブレース下端は, 野縁受け方向では野縁受 けにビス止めとし, 野縁方向ではブレース受け材 A にビス止めされ ている。なお, ブレース受け材 A は, ハンガーに設置されたブレー ス受け材 B にビス止めされている。ブレース接合部材（ブレースホ ルダー）は，吊りボルトに対して閉断面を成しており，ブレース面 内の角度が自在に変えられるタイプである。試験体は A, B の 2 体 であり, 試験体 A は文献 15)で実施されたもの, 試験体 B は A の耐 震仕様クリップについて, 野縁方向に滑動しないように金物をあて がいビス止めで拘束し（写真 1)，ブレースを増厚したものである。

実験装置を図 2 に示す。実験装置は, 振動台上の加力フレームの
* 清水建設(株)技術研究所 工学修士

$* *$ 清水建設(株)技術研究所 博士 (工学)
Institute of Technology, Shimizu Corporation, M. Eng.

Institute of Technology, Shimizu Corporation, Dr. Eng. 

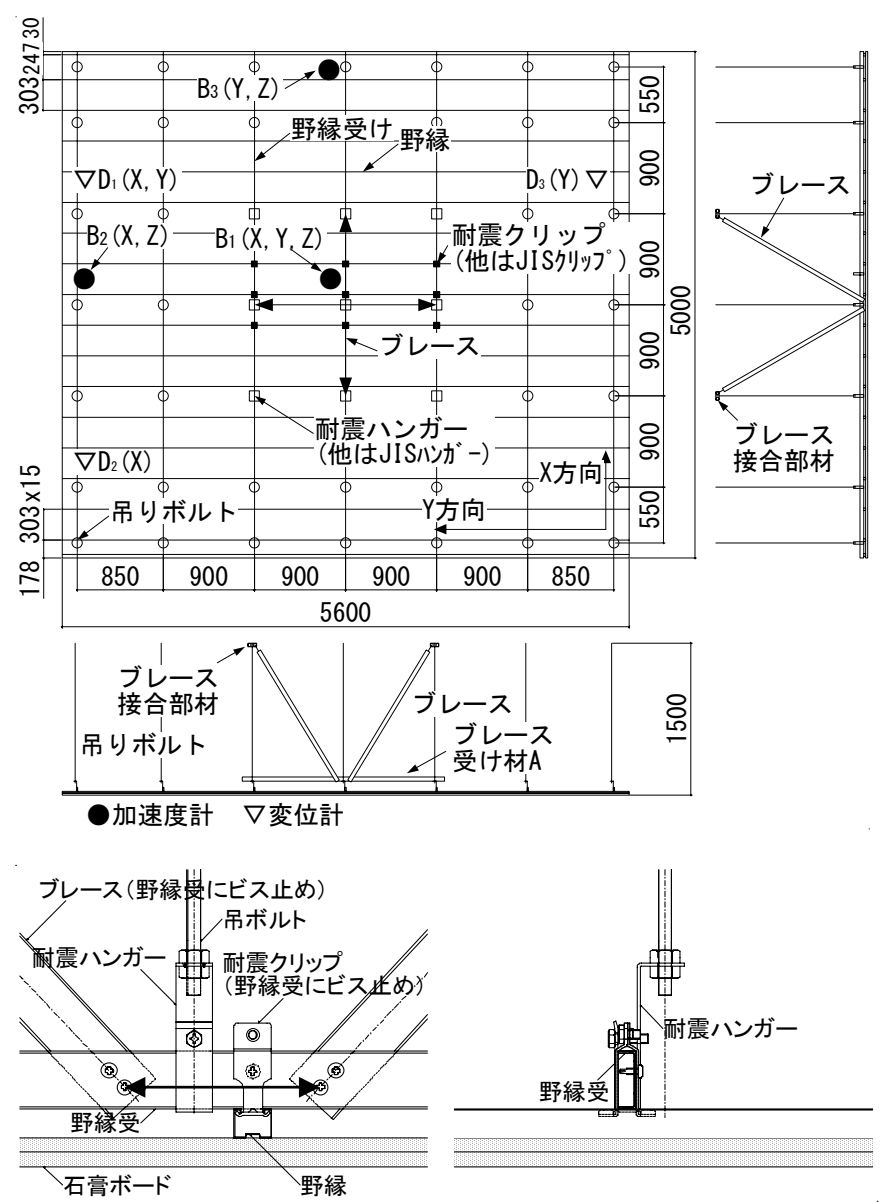

$X$ 方向ブレース周り（矢印のビス間隔は $200 \mathrm{~mm}$ 以下）

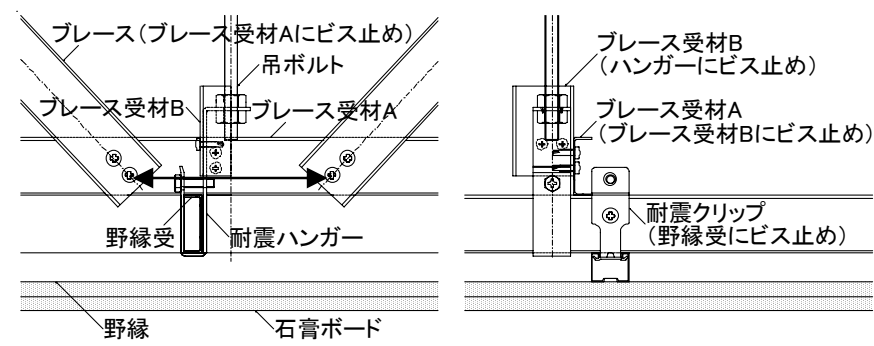

$Y$ 方向ブレース周り（矢印のビス間隔は $200 \mathrm{~mm}$ 以下）

図 1 天井試験体概要

表 1 試験体諸元

\begin{tabular}{|c|c|c|}
\hline 部位 & 試験体A & 試験体B \\
\hline 天井ボード & \multicolumn{2}{|c|}{ 2枚張り（計19mm） } \\
\hline 野縁・野縁受け & \multicolumn{2}{|c|}{ JIS C19 $\cdot$ C38 } \\
\hline ボード縁のクリップ & JIS規格品 $(19$ 形, $\mathrm{t}=0.6)$ & 耐震仕様 $*(\mathrm{t}=1.6)$ \\
\hline ブレース周りのクリップ & 耐震仕様 $(\mathrm{t}=1.6)$ & 耐震仕様*(滑り拘束) \\
\hline その他のクリップ & \multicolumn{2}{|c|}{ JIS規格品 $(19$ 形, $\mathrm{t}=0.6)$} \\
\hline ブレース周辺ハンガー & \multicolumn{2}{|c|}{ 耐震ハンガー** $(\mathrm{t}=2) \times 9$ 個 } \\
\hline その他のハンガー & \multicolumn{2}{|c|}{ その他 : JIS規格品 (19形, $\mathrm{t}=2)$} \\
\hline ブレース & 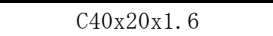 & $C 40 \times 20 \times 2.3$ \\
\hline ブレース水平受け材 $A \cdot B$ & \multicolumn{2}{|c|}{ C40×20x1.6 } \\
\hline ブレースホルダー & \multicolumn{2}{|c|}{ (株)サワタB-S-W3/8用 } \\
\hline 吊りボルト & \multicolumn{2}{|c|}{$W 3 / 8$} \\
\hline
\end{tabular}

* 耐震仕様クリップ：(株)能重製作所 耐風圧 $\mathrm{SC}$

**耐震ハンガー : (株)オクジュー ハンガーN 
表 2 加カプログラム

\begin{tabular}{|c|c|c|c|c|}
\hline & \multicolumn{2}{|c|}{ 試験体 $\mathrm{A}\left(\mathrm{cm} / \mathrm{sec}^{2}\right)$} & \multicolumn{2}{|c|}{ 試験体B $\left(\mathrm{cm} / \mathrm{sec}^{2}\right)$} \\
\hline No. & 内容 & 方向/レベル & 内容 & 方向/レベル \\
\hline 1 & 㕲仆ノイズ & $X: 100$ & 㕲仆ノイズ & $\mathrm{Y}: 100$ \\
\hline 2 & 㕲仆ノイズ & $\mathrm{Y}: 100$ & 㕲仆ノイズ & $Z: 100$ \\
\hline 3 & 㕲仆ノイ゙ & $Z: 100$ & 低層波 & YZ:190 \\
\hline 4 & E1 Centro & $X: 150$ & 高層波 & YZ:582 \\
\hline 5 & E1 Centro & $X: 300$ & E1 Centro & $\mathrm{Y}: 600, \mathrm{Z}: 300$ \\
\hline 6 & E1 Centro & $X: 600$ & 杖イトイズ & $X: 100$ \\
\hline 7 & E1 Centro & $Y: 150$ & 高層波 & $\mathrm{XZ}: 582$ \\
\hline 8 & E1 Centro & $Y: 300$ & E1 Centro & $X: 600, Z: 300$ \\
\hline 9 & E1 Centro & $\mathrm{Y}: 600$ & 低層波 & $X Z: 190$ \\
\hline
\end{tabular}
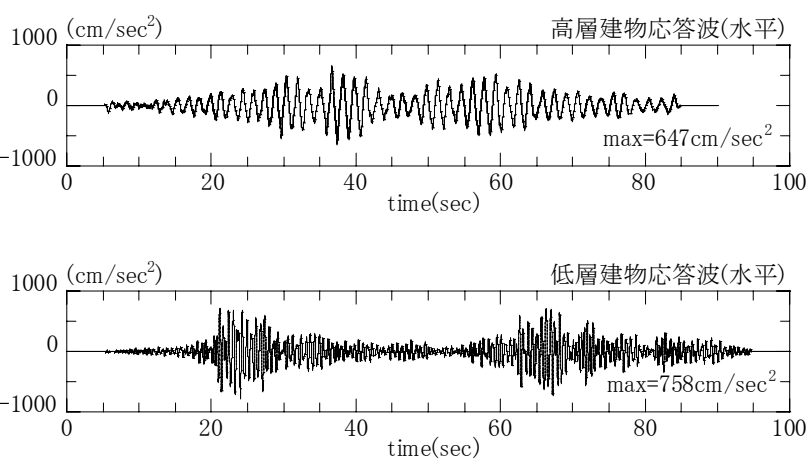

図 3 入力波形（低層および高層応答波 100\%)
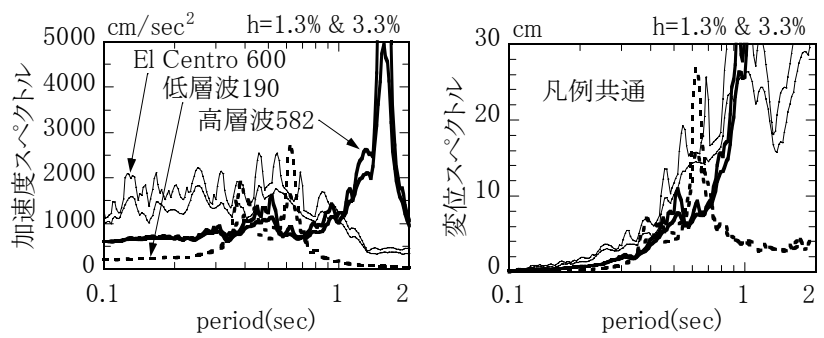

図 4 入カの応答スペクトル

されており，試験体 $\mathrm{A}$ に比べて滑動を抑制することができた。X方 向加振時の試験体 B には, 入力レベルが小さいうちは目視上特段の 損傷は見られず，El Centro $600 \mathrm{~cm} / \mathrm{sec}^{2}$ 入力でもブレースの座屈は弾 性的なものに留まり，顕著な残留変形は残らなかった（写真 3 )。
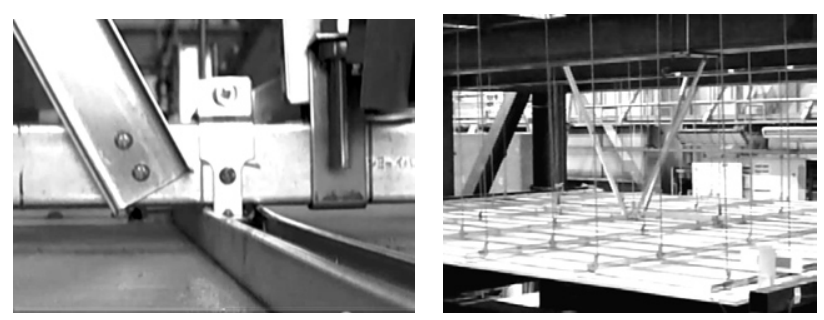

写真 2 加振後の野縁の開き

写真 3 加振後のブレースの様子

\section{3 実験結果}

\section{3. 1 ホワイトノイズ加振による振動特性}

試験体 $\mathrm{A}$ の計測加速度による天井／加力フレームの伝達関数（計 測点 $\mathrm{B}_{1} / \mathrm{F}_{1}$ ) を図 5 に示す (Parzen Window $0.1 \mathrm{~Hz}$ )。X, $\mathrm{Y}$ の固有振 動数（ピークの振動数）は $6.2 \mathrm{~Hz}$ と $5.0 \mathrm{~Hz}$ であった。ピーク高さか ら減衰はそれぞれ $1.3 \% ， 3.3 \%$ 程度と見なせる。

同じく, 試験体 B の伝達関数を図 6 に示す。 $\mathrm{Y}$ 方向は試験体 $\mathrm{A}$ の 固有振動数とほぼ同じである。X 方向の固有振動数は試験体 $\mathrm{A}$ に比 べ低下しており，その原因はホワイトノイズ加振の前に，Y 方向の 地震加振を実施したためと考えられる。Y 方向の加振時には, 耐震 クリップと野縁受けの滑動は拘束されていても, 野縁受けは傾斜を 生じており，野縁と野縁受けには部材の接触部の局部的な変形，而 震クリップと野縁受けを貫通するビス孔の拡大などの損傷が生じ, それが X方向の微小な振幅における振動周期の伸びの原因と推察さ れる。

試験体 $\mathrm{B}$ の伝達関数の振幅は, 試験体 $\mathrm{A}$ のそれに比べて小さく, 減衰を概算すると X 方向 $8 \%, \mathrm{Y}$ 方向 $6 \%$ 程度となる。なお，ホワイ 卜ノイズ加振における天井の最大応答を表 3 に示す。加速度は計測 点 $\mathrm{B}_{1}$, 変位は天井両端の平均值である。最大応答変位は各方向とも 1.2〜1.3mm である。
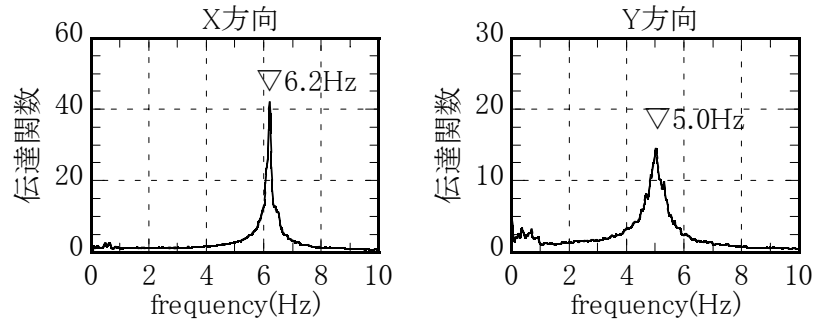

図 5 試験体 A の伝達関数
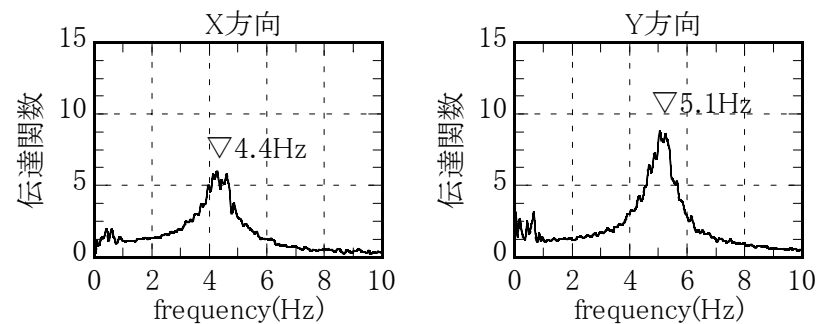

図 6 試験体 B の伝達関数 $(X$ 方向はY 方向加振後 $)$

表 3 ホワイトノイズ加振における天井面の最大応答

\begin{tabular}{|c|c|c|c|c|}
\hline \multirow{2}{*}{ 方 } & \multicolumn{2}{|c|}{ 最大加速度 $\left(\mathrm{cm} / \mathrm{sec}^{2}\right)$} & \multicolumn{2}{|c|}{ 最大変位 $(\mathrm{mm})$} \\
\cline { 1 - 5 } & $\mathrm{A}$ & $\mathrm{B}$ & $\mathrm{A}$ & $\mathrm{B}$ \\
\hline $\mathrm{X}$ & 173 & 91.4 & 1.25 & 1.31 \\
\hline $\mathrm{Y}$ & 103 & 117 & 1.34 & 1.22 \\
\hline
\end{tabular}

\section{3. 2 地震入力に対する応答}

試験体 $\mathrm{A}$ の応答波形の例を図 7 に, 各地震応答から求めた試験体 の伝達関数を図 8 に, 最大值の一覧を表 4 に示寸。加速度波形はノ イズ除去のため $20 \mathrm{~Hz}$ のローパスフィルタを掛けた。変位には残留 
変位を歪めないためにフィルタを掛けていない。変位 D1, D2 は同 位相の波形で最大值の差も小さいため, 以後, 変位は計測した 2 点 の平均を用い, 加速度は重心に近い $\mathrm{B}_{1}$ を用いる。伝達関数には, 応 答レベルの増加とともに長周期化と減衰の増加が認められる。最大 の応答レベルについては, X 方向は $1 \mathrm{G}$ (重力加速度)を超過してい るが(質量 $462 \mathrm{~kg}$ に相当する慣性力 $4.53 \mathrm{kN}$ 以上を負担しているが), $\mathrm{Y}$ 方向は若干これを下回る。

試験体 B の伝達関数を図 9 に, 応答の最大值を表 5 に示す。応答 波形は解析結果とともに後述する。X 方向の場合, 試験体 A では, El Centro NS $600 \mathrm{~cm} / \mathrm{sec}^{2}$ 入力において, 1G を超え, 変位も $40 \mathrm{~mm}$ 以 下であったが, 試験体 B でも, 概ね同程度の応答が得られている。 試験体 A では X-Y 方向の順に, 試験体 B では Y-X の順に加振を実 施し, 試験体 B の X方向のホワイトノイズ加振による共振振動数は, 試験体 A のそれに比べて低下していたが，振幅の大きい応答レベル はそれほど差が生じていない。

Y 方向の場合, 試験体 A では El Centro NS $600 \mathrm{~cm} / \mathrm{sec}^{2}$ 入力におい て $1 \mathrm{G}$ に達せず, 変位は $60 \mathrm{~mm}$ を超えたが, 試験体 B では $1 \mathrm{G}$ を超 え, 変位も $40 \mathrm{~mm}$ 以下となっている。このように変位が抑制された ことは, 耐震クリップの滑動の拘束の有効性を示すものであると考 えられる。

伝達関数を見ると, Y 方向では, 応答レベルの小さい低層波, 高 層波では固有振動数の変動は小さく, El Centro $600 \mathrm{~cm} / \mathrm{sec}^{2}$ で大きく 低下した。X方向では, 高層波から El Centro $600 \mathrm{~cm} / \mathrm{sec}^{2}$ の入力の変 化で固有振動数が大きく低下して, 次に入力された低層波では固有 振動数の変動はなく, ピーク高さも高くなった。以上のように, 固 有振動数の変化は, 応答変位の大きさと, 大きな変位応答により低 下した剛性が, その後の小さな変位振幅時には回復しない性状とに 関連づけることができる。
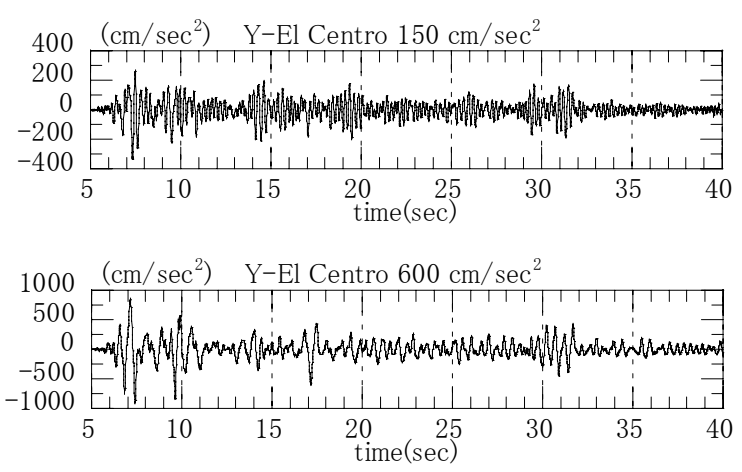

図 7 試験体 A の応答波形の例
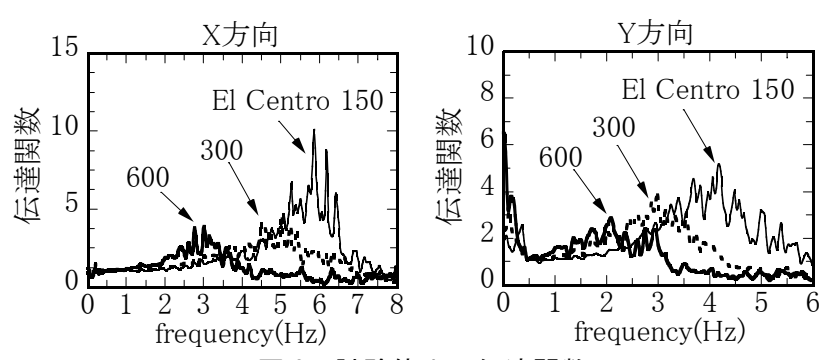

図 8 試験体 A の伝達関数
表 4 地震入カにおける試験体 A の天井面最大応答

\begin{tabular}{|c|c|c|c|c|c|c|}
\hline \multirow{2}{*}{$\begin{array}{c}\text { 方 } \\
\text { 向 }\end{array}$} & $\begin{array}{c}\text { 入カレベル } \\
\left(\mathrm{cm} / \mathrm{sec}^{2}\right)\end{array}$ & \multicolumn{2}{|c|}{ 加速度 $\left(\mathrm{cm} / \mathrm{sec}^{2}\right)$} & \multicolumn{3}{|c|}{ 変位 $(\mathrm{mm})$} \\
\cline { 2 - 7 } & B1 & B2. or. B3 & D1 & D2 & 平均 \\
\hline \multirow{4}{*}{$X$} & E1 Centro150 & 467 & 466 & 5.4 & 6.0 & 5.7 \\
\cline { 2 - 7 } & E1 Centro300 & 645 & 627 & 12.7 & 11.4 & 10.8 \\
\cline { 2 - 8 } & E1 Centro600 & 1094 & 1082 & 31.1 & 30.5 & 30.8 \\
\hline \multirow{4}{*}{$Y$} & E1 Centro150 & 337 & 362 & 7.3 & 7.7 & 7.5 \\
\cline { 2 - 7 } & E1 Centro300 & 601 & 631 & 20.3 & 20.3 & 20.1 \\
\cline { 2 - 7 } & E1 Centro600 & 913 & 963 & 61.2 & 62.0 & 61.6 \\
\hline
\end{tabular}
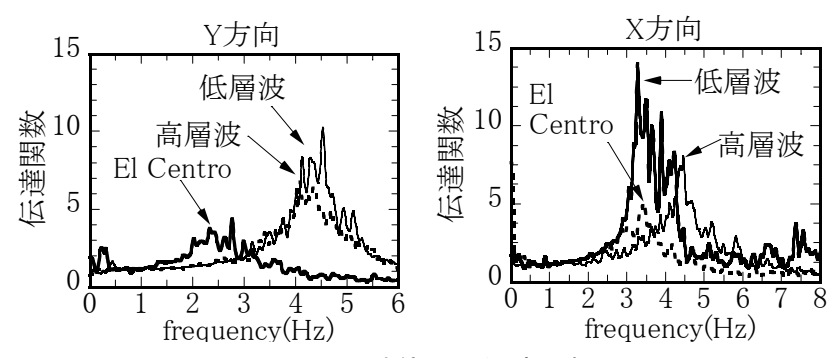

図 9 試験体 B の伝達関数

表 5 地震入力における試験体 B の天井面の最大応答

\begin{tabular}{|c|c|c|c|c|c|c|}
\hline \multirow{2}{*}{$\begin{array}{c}\text { 方 } \\
\text { 向 }\end{array}$} & $\begin{array}{c}\text { 入カレベル } \\
\left(\mathrm{cm} / \mathrm{sec}^{2}\right)\end{array}$ & \multicolumn{2}{|c|}{ 加速度 $\left(\mathrm{cm} / \mathrm{sec}^{2}\right)$} & \multicolumn{3}{|c|}{ 変位 $(\mathrm{mm})$} \\
\cline { 3 - 7 } & B1 & B2.or. B3 & D1 & D2 & 平均 \\
\hline \multirow{3}{*}{$\mathrm{YZ}$} & 低層波190 & 386 & 405 & 7.1 & 7.1 & 7.1 \\
\cline { 2 - 7 } & 高層波582 & 463 & 487 & 8.8 & 8.5 & 8.7 \\
\cline { 2 - 7 } & $\mathrm{E} 1$ Centro600 & 1258 & 1331 & 38.7 & 37.6 & 38.1 \\
\hline \multirow{3}{*}{$\mathrm{XZ}$} & 高層波582 & 505 & 542 & 7.9 & 10.0 & 8.3 \\
\cline { 2 - 7 } & $\mathrm{E} 1$ Centro600 & 1062 & 1182 & 29.2 & 36.7 & 32.0 \\
\cline { 2 - 7 } & 低層波190 & 503 & 520 & 11.4 & 11.3 & 10.8 \\
\hline
\end{tabular}

\section{3. シミュレーション解析}

\section{1 解析モデル}

本節では, 前節で述べた動的加振実験結果に対するシミュレーシ ヨン解析について述べる。試験体 A, B は偏心の小さい平坦な天井 パネルであるため, 解析モデルは図 10 に示す 3 節点モデルとした。 本工法による天井システムの力学特性は, 補強金物とブレース部分 の特性が支配的である。筆者らは, その特性を小規模実験で別途把 握しており，その概要を注 1)に示す。対象はブレースを含んだ $2 \mathrm{~m}^{2}$ 規模の天井ユニットで, 金物の仕様は, 本論の試験体 A と同様であ る。動的加振実験同様, 野縁受け方向ではブレースの座屈（最大耐 力 $4.95 \mathrm{kN}$ ), 野縁方向では耐震クリップの滑動と野縁受けの曲げ変 形（最大耐力 $4.92 \mathrm{kN}$ ) が生じた。解析モデルは, ブレース部分のト ラス要素, 耐震クリップ部分のばね要素, さらに負担力の限界を表 すばね要素からなり, 前二者はバイリニアとバイリニアスリップ型 の復元力を有する 2 要素を並列させてモデル化されている（図 11, 図 12)。注 1)に述べたとおり, 本モデルは概ね静的繰り返し加力実 験による天井ユニットの荷重変形関係を模擬している。

解析モデルの諸元を表 6 に示寸。これらの諸元は, 静的繰り返し 加力実験の荷重変形関係の包絡線からトリリニア型のスケルトン, 第一折れ点の荷重, 戻り勾配を決めれば, 他のパラメータは一意に 決まる。表中の「耐力」は, 試験体が負担できる最大耐力で, 試験 
体 $\mathrm{A}$ の X 方向と試験体 $\mathrm{B}$ の X および $\mathrm{Y}$ 方向は主としてブレースの 座屈, 試験体 $\mathrm{A}$ の $\mathrm{Y}$ 方向では, 耐震クリップの滑動と野縁受けの曲 げ変形によって決まる。ここでは, 最大加速度および静的繰り返し 加力実験の最大耐力を参考に定めており, 試験体 $\mathrm{A} の \mathrm{X}$ 方向は, 静 的繰り返し加力実験結果の $95 \%, \mathrm{Y}$ 方向は $90 \%$, 試験体 B の X 方 向は $99 \%, Y$ 方向は $114 \%$ に当たる。なお, 試験体 B の耐震クリッ プは野縁方向に対してビスにより変位拘束されているため, 上記の クリップモデルに対して, スリップ性状を除いたスケルトンとし, バイリニア型復元力を与えた。減衰は試験体 $\mathrm{A}, \mathrm{B}$ とも, $\mathrm{X}$ 方向は モデルの 1 次固有振動数に対して $1.2 \%, Y$ 方向は $3.3 \%$ の瞬間剛性 比例型減衰とした。
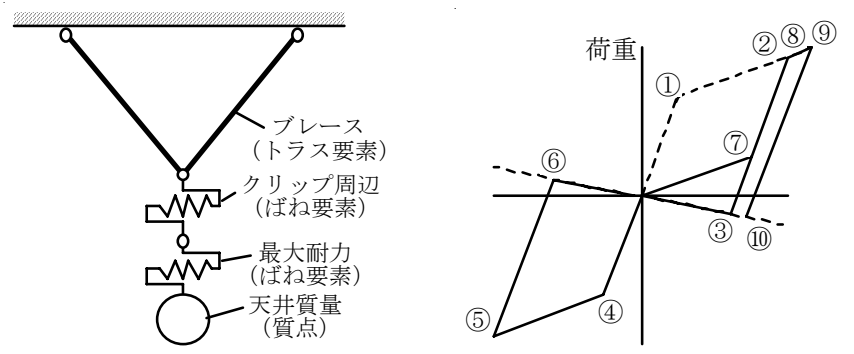

図 10 解析モデル

図 12 バイリニアスリップの履歴則

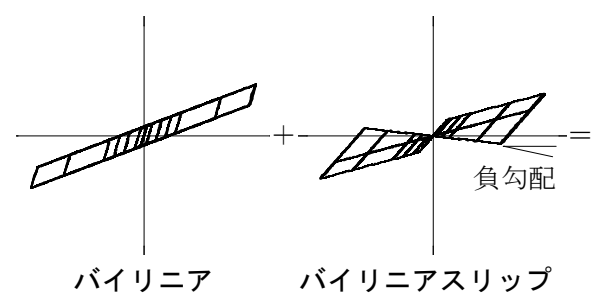

図 11 復元力特性の与え方

表 6 解析モデル諸元

\begin{tabular}{|c|c|c|c|c|c|c|}
\hline \multicolumn{2}{|c|}{ 試験体と部位 } & 復元力特性 & $\begin{array}{l}\text { 初期剛性 } \\
(\mathrm{kN} / \mathrm{mm})\end{array}$ & \begin{tabular}{|c} 
降伏変位 \\
(mm)
\end{tabular} & \begin{tabular}{|c|} 
2次 \\
剛性比
\end{tabular} & 備考 \\
\hline \multirow{7}{*}{ A } & \multirow{2}{*}{$\mathrm{X}:$ ブレーオ } & バイリニア & 2.25 & 0.4 & 0.111 & \multirow{2}{*}{$\begin{array}{l}\text { 沙ップの } \\
\text { 負勾配0 }\end{array}$} \\
\hline & & スリップバイリニア & 2.75 & 1.0 & 0.236 & \\
\hline & Y:ブVーオ & \multicolumn{4}{|c|}{ X方向に同じ } & \\
\hline & \multirow{2}{*}{$\mathrm{X}:$ クリッフ } & バイリニア & 0.9 & 0.667 & 0.111 & \multirow{2}{*}{$\begin{array}{l}\text { 耐力 } 4.7 \mathrm{kN} \\
\text { 負勾配 } 0.1\end{array}$} \\
\hline & & スリップベイリニア & 0.3 & 3.167 & 0.2333 & \\
\hline & \multirow{2}{*}{$\mathrm{Y}:$ クリップ } & バイリニア & 0.25 & 2.0 & 0.28 & \multirow{2}{*}{$\begin{array}{l}\text { 耐力 } 4.43 \mathrm{kN} \\
\text { 負勾配 } 0.1\end{array}$} \\
\hline & & スリップバイリニア & 0.15 & 7.455 & 0 & \\
\hline \multirow{3}{*}{ B } & ブレース & \multicolumn{4}{|c|}{ 試験体Aに同じ } & \\
\hline & 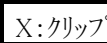 & \multicolumn{4}{|c|}{ 試験体Aに同じ } & 耐力 $4.89 \mathrm{kN}$ \\
\hline & Y:クリップ & バイリニア & 0.4 & 2.0 & - & 耐力 $5.62 \mathrm{kN}$ \\
\hline
\end{tabular}

\section{2 解析結果}

モデルの固有值解析による 1 次固有振動数を, 前節で述べた試験 体の固有振動数および注 1)に示した $2 \mathrm{~m}^{2}$ 規模の試験体の初期剛性か ら得られる值と比較して表 7 に示す。( )の数值は, ホワイトノイズ による值との比である。 $28 \mathrm{~m}^{2}$ 規模の試験体の水平剛性は, ブレース 部分の剛性が支配的であり, ブレースを含む $2 \mathrm{~m}^{2}$ 規模の実験結果か らの推定值との差は Y 方向で 1 割程度である。解析モデルは $2 \mathrm{~m}^{2}$ 規
模の試験体の静的繰り返し加力実験の結果を反映しているが, 第一 折れ点の取り方により初期剛性が X方向で大きめとなっているもの の，実験值との差はやはり 1 割程度に留まる。

試験体 $\mathrm{A}$ の実験および解析による加速度および变位波形の例を図 13, 図 14 に, 最大応答值の比較を表 8 に示す。実験值と同様, 加速 度には $20 \mathrm{~Hz}$ のローパスフィルタを掛け, 変位にはフィルタを掛け ていない。El Centro NS 入力に対する解析波形は, 最大值, 位相と も概ね実験結果を模擬しており, 振幅の小さい場合を除くと, 最大 值の実験值に対する誤差は 1 割程度である。

試験体 B の実験および解析による加速度および变位波形の例を図 15 , 図 16 に, 最大応答值の比較を表 9 に, 試験体 $\mathrm{A}, \mathrm{B}$ の応答の一 覧を図 17 に示寸 (図中, 波線は $\pm 10 \%$ )。解析波形は X 方向低層波 の場合を除き, 最大值, 位相とも概祇実験結果を模擬しており, 振 幅の小さい場合を除くと, 最大值の実験值に対する誤差は 1 割程度 である。低層応答波については, 図 3 に示した通り，20３0 秒の区 間の他に 60〜 70 秒で大きな振幅を有する。図 15 にある低層応答波 入力の当該区間の応答を図 18 に示す。解析結果は, 当該区間でも概 衫実験結果を模擬している。高層波入力については, 入力の卓越周 期は 1.6 秒であり, 応答波形にもその成分は見られるが, それ以外 に試験体の固有振動数成分が高周波成分として見られる。図 15 にあ る高層応答波入力を拡大して図 19 に示寸。解析結果は, 実験結果に 見られるこの高周波成分も模擬している。

$\mathrm{X}$ 方向の低層波の場合は, 直前に El Centro NS $600 \mathrm{~cm} / \mathrm{sec}^{2}$ 入力に よる $30 \mathrm{~mm}$ 程度の変位応答を経験している。解析では繰り返し振幅 による剛性低下を考慮しているが, そうした大変形を経験した後で は，応答精度は低下した。そうした場合を除けば，解析モデルは， 中〜大変形の領域で，3 種類の入力波に対する実験結果をよく再現 している。

表 71 次固有振動数の比較

\begin{tabular}{|c|c|c|}
\hline & X方向 $(\mathrm{Hz})$ & Y方向 $(\mathrm{Hz})$ \\
\hline $28 \mathrm{~m}^{2}$ 試験体 (杖仆)イズ 結果) & 6.2 & 5.0 \\
\hline \multirow{2}{*}{$2 \mathrm{~m}^{2}$ 試験体 (初期剛性值) } & 6.2 & 4.6 \\
\cline { 2 - 3 } & $(1.01)$ & $(0.91)$ \\
\hline \multirow{2}{*}{ 解析モデル (固有值解析) } & 6.7 & 4.5 \\
\cline { 2 - 4 } & $(1.08)$ & $(0.90)$ \\
\hline
\end{tabular}

表 8 解析による試験体 A の天井面の最大応答

\begin{tabular}{|c|c|c|c|c|c|}
\hline \multirow{2}{*}{$\begin{array}{c}\text { 方 } \\
\text { 向 }\end{array}$} & \multirow{2}{*}{ 人カレベル } & \multicolumn{2}{|c|}{ 加速度 $\left(\mathrm{cm} / \mathrm{sec}^{2}\right)$} & \multicolumn{2}{|c|}{ 変位 $(\mathrm{mm})$} \\
\cline { 3 - 6 } & & 最大值 & 実験值比 & 最大值 & 実験值比 \\
\hline \multirow{3}{*}{$X$} & E1 Centro150 & 425 & 0.91 & 4.61 & 0.81 \\
\cline { 2 - 6 } & E1 Centro300 & 644 & 1.00 & 11.4 & 1.06 \\
\cline { 2 - 6 } & E1 Centro600 & 1091 & 1.00 & 34.5 & 1.12 \\
\hline \multirow{3}{*}{$Y$} & E1 Centro150 & 419 & 1.24 & 7.9 & 1.05 \\
\cline { 2 - 6 } & E1 Centro300 & 585 & 0.97 & 18.6 & 0.93 \\
\cline { 2 - 6 } & E1 Centro600 & 988 & 1.08 & 54.3 & 0.88 \\
\hline
\end{tabular}

\section{4. 結論}

文献 15)で提案したブレース周辺部を部分補強した天井工法に関 し, $28 \mathrm{~m}^{2}$ に 1 対の $\mathrm{V}$ 字形にブレースを設置した天井システムに対し 

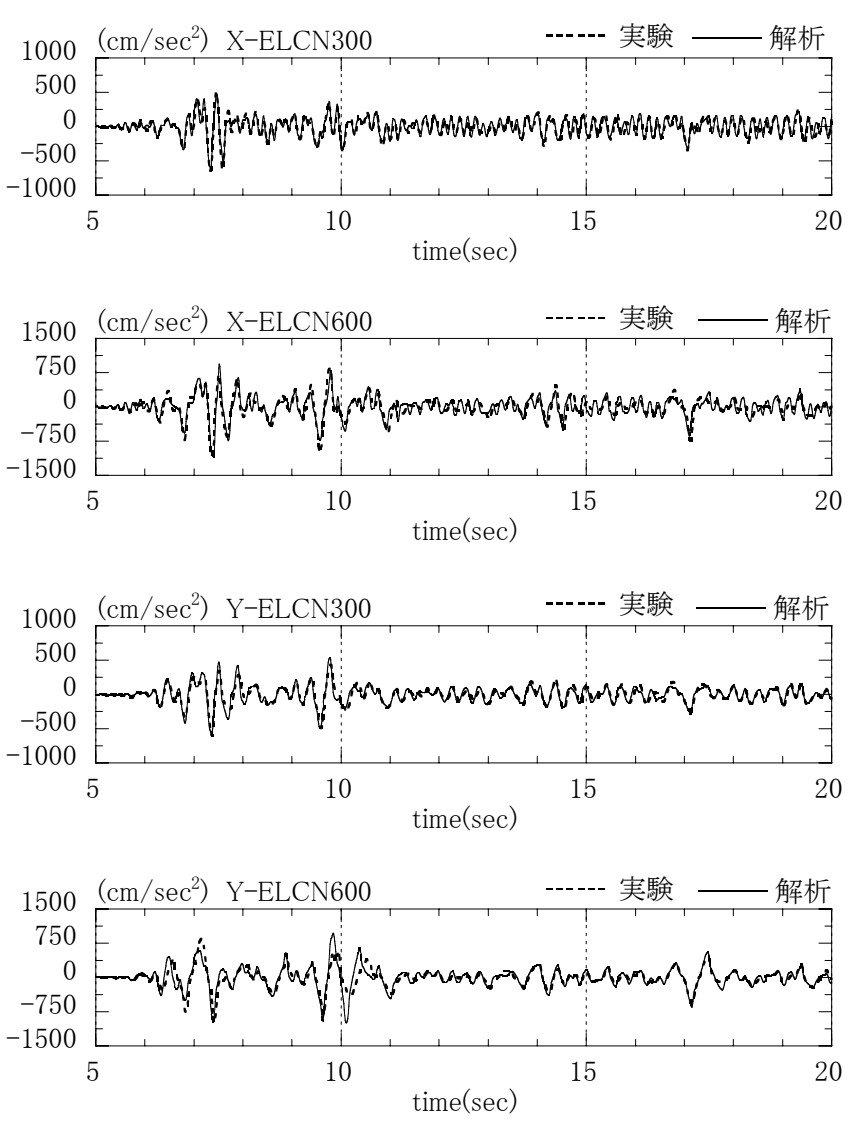

図 13 試験体 A の天井面の加速度応答波形の比較
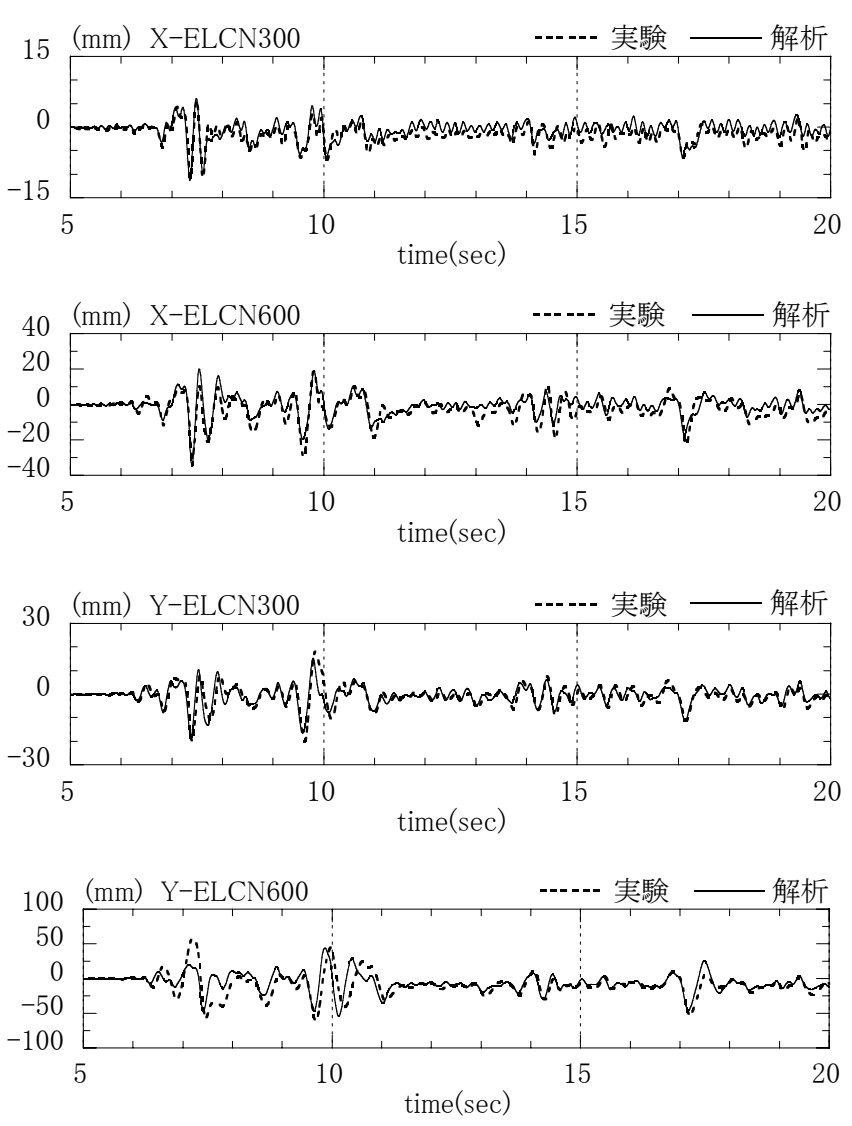

図 14 試験体 $\mathrm{A}$ の天井面の変位応答波形の比較
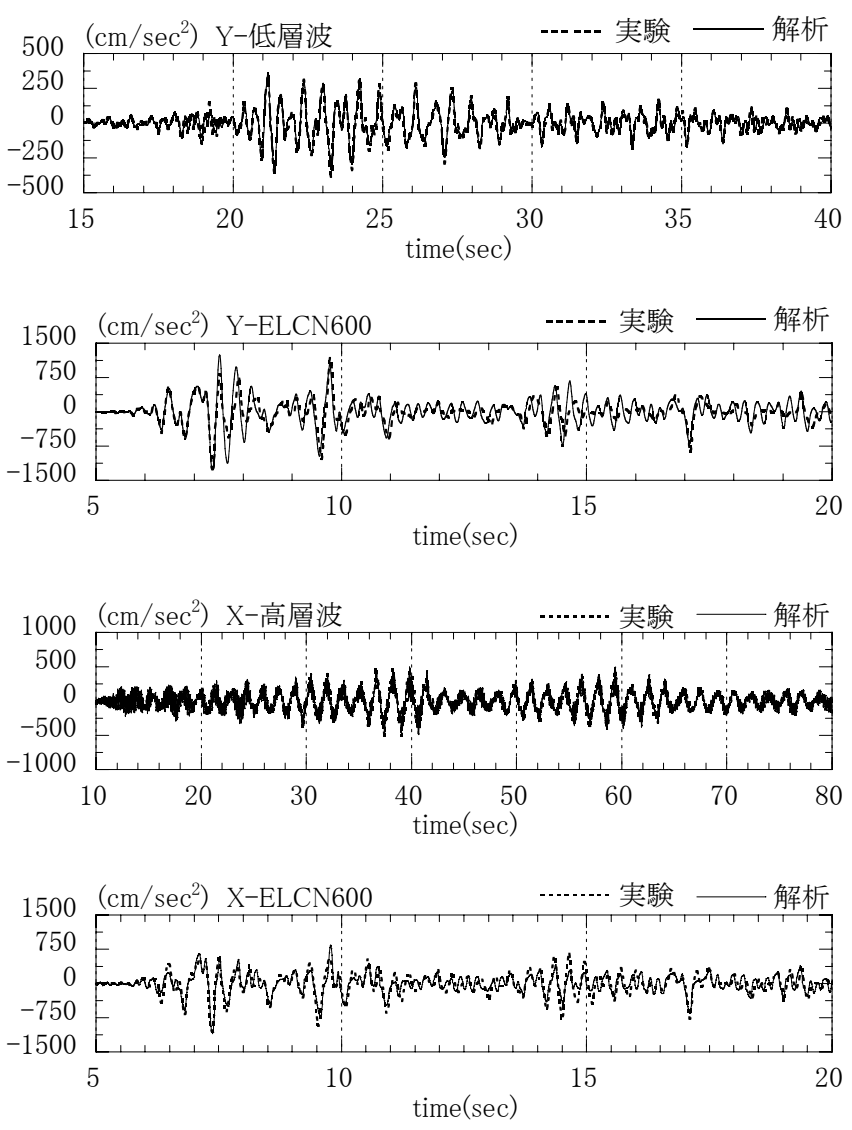

図 15 試験体 B の天井面の加速度応答波形の比較
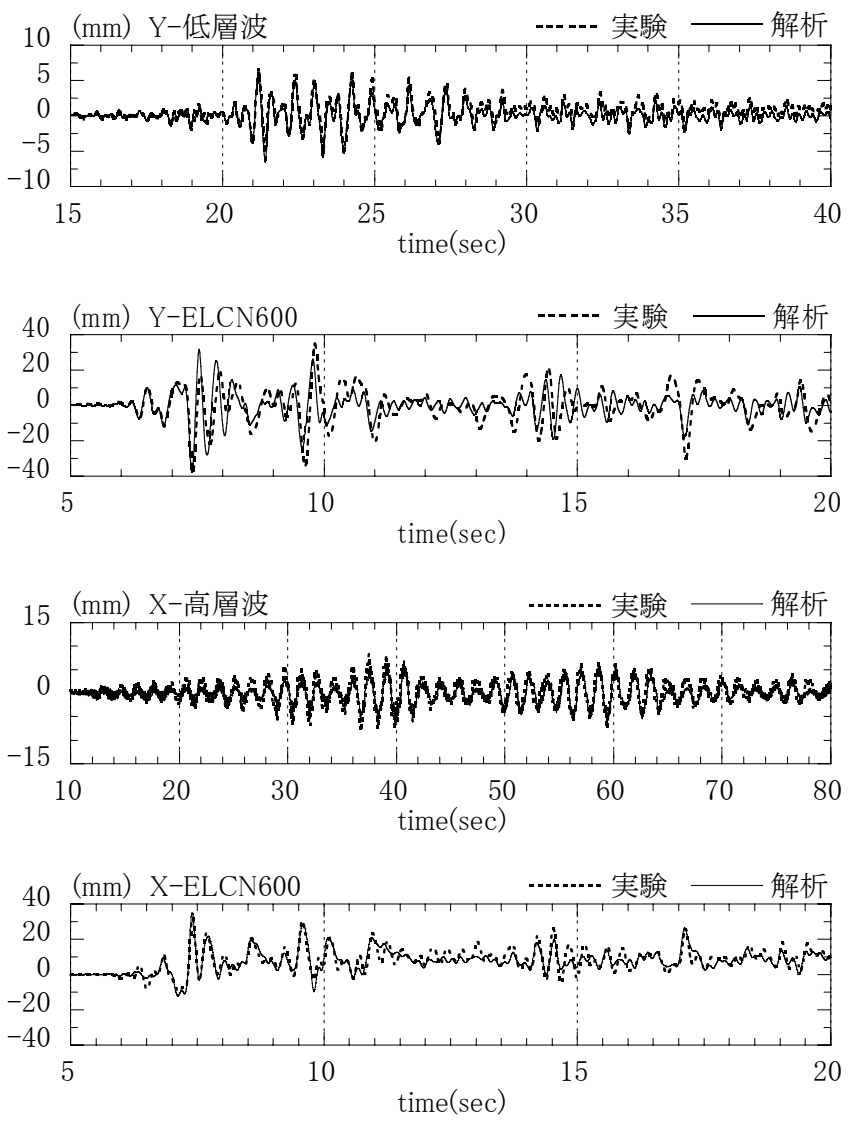

図 16 試験体 B の天井面の変位応答波形の比較 
表 9 解析による試験体 B の天井面の最大応答

\begin{tabular}{|c|c|c|c|c|c|}
\hline \multirow{2}{*}{$\begin{array}{c}\text { 方 } \\
\text { 向 }\end{array}$} & \multirow{2}{*}{ 入力レベ } & \multicolumn{2}{|c|}{ 加速度 $\left(\mathrm{cm} / \mathrm{sec}^{2}\right)$} & \multicolumn{2}{|c|}{ 変位 $(\mathrm{mm})$} \\
\cline { 3 - 6 } & & 最大值 & 実験值比 & 最大值 & 実験值比 \\
\hline \multirow{3}{*}{$\mathrm{YZ}$} & 低層波 & 364 & 0.94 & 6.66 & 0.94 \\
\cline { 2 - 6 } & 高層波 & 460 & 0.99 & 8.92 & 1.03 \\
\cline { 2 - 6 } & $\mathrm{E} 1$ Centro600 & 1253 & 1.00 & 37.6 & 0.99 \\
\hline \multirow{3}{*}{$\mathrm{XZ}$} & 高層波 & 494 & 0.98 & 6.88 & 0.83 \\
\cline { 2 - 6 } & $\mathrm{E} 1$ Centro600 & 1092 & 1.03 & 35.2 & 1.10 \\
\cline { 2 - 6 } & 低層波 & 396 & 0.79 & 4.02 & 0.37 \\
\hline
\end{tabular}
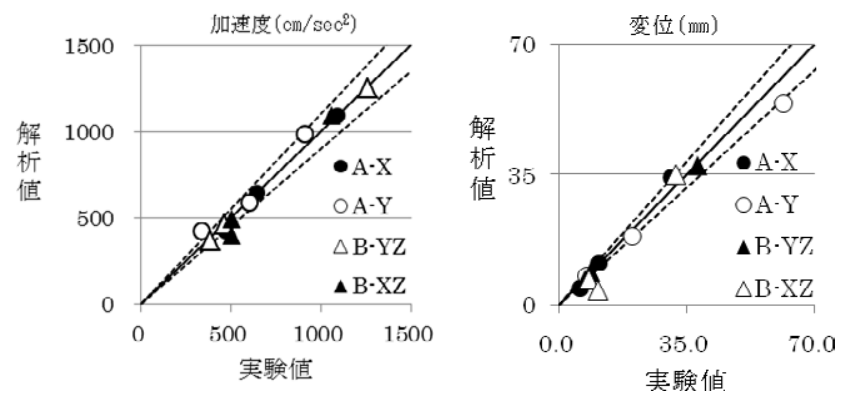

図 17 実験値と解析値の比較

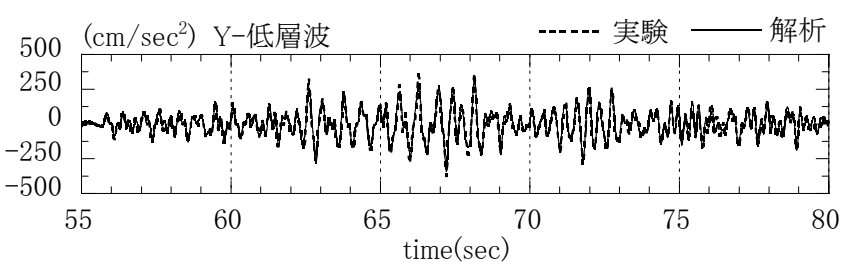

図 18 低層波入力の時刻 55 80 秒における加速度応答波形

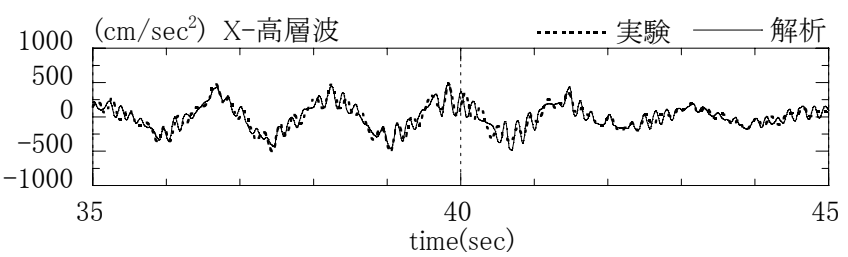

図 19 高層波入力の加速度応答波形の拡大図

て，地震観測波および建物解析応答波を用いた加振実験を行った。 また, 本工法の部分試験体 ( $2 \mathrm{~m}^{2}$ 規模) に対して行った静的加力実 験結果に基づく解析モデルを用いて, 動的加振実験のシミュレーシ ヨン解析を行った。得られた知見は以下のようにまとめられる。

1) 天井システムの固有振動数は, 天井ユニットの静的繰り返し加力 試験における小変形時の等価剛性から概ね説明できる。

2) 本工法による天井システムの性能を応答加速度から見ると, X 方 向については, 2 体の試験体とも, 最大で $1 \mathrm{G}$ の加速度に相当す る慣性力（4.53kN）以上を負担し，ブレース断面の小さい試験体 $\mathrm{A}$ では座屈が見られ, 最大変位は $30 \mathrm{~mm}$ 程度であった。また, 加 力順序を試験体 A では X-Y の順, 試験体 B では Y-X の順とした が，ホワイトノイズ加振による固有振動数の変化に係わらず，ほ ぼ同程度の応答を示した。

3) Y 方向については, 試験体 A では耐震クリップが滑動し, 最大応 答加速度も $1 \mathrm{G}$ をやや下回り, 最大変位も $60 \mathrm{~mm}$ 程度と大きかっ たが，滑動を拘束した試験体 B では最大応答加速度は $1 \mathrm{G}$ を超過
し, 最大変位も $40 \mathrm{~mm}$ 以下となり, 補剛の効果が認められた。

4) $2 \mathrm{~m}^{2}$ 規模の天井ユニットの静的加力実験からモデル化したブレー ス十クリップモデルを用いた動的解析モデルは， $28 \mathrm{~m}^{2}$ 規模の天 井システムの複数種類の入力波による加振実験結果を, 最大応答 加速度，最大応答変位および波形位相に関して，概ね再現した。

5) 試験体 B に関して, 実験で見られた耐震クリップの野縁方向の滑 動拘束の効果は，解析においても再現された。

6) 解析モデルは繰り返しによる影響を考慮しているが, 大変形を受 けた後の小さな応答レベルの挙動に対しては，精度は低下する。

\section{謝辞}

本研究における加振実験においてご協力頂いた株式会社ミルック スの安武浩通氏，工藤夕雅氏に深く感謝の意を表します。

\section{参考文献}

1） 日本建築学会, 非構造部材の耐震設計施工指針・同解説および而震設計施 工要領, 2003

2）西山功, 伊藤弘, 西田和生, 梁一承: 芸予地震による体育館天井の落下 被害の調査とその対策, 日本建築学会技術報告集, 第 16 号, pp.367-372, 2002.12

3）川口健一, 吉中進, 大塚彩, 片山慎一朗: 新潟県中越地震と同中越沖地 震における大規模集客施設内部の非構造材（吊り天井）被害の比較, 日 本建築学会技術報告集，第 14 卷第 27 号，pp.73-78，2008.6

4) 中本康, 北川則昭, ほか 5 名 : 釧路空港ターミナルビル天井材落下に関 する研究 その $1 \sim 5$, 日本建築学会大会学術講演梗概集, B-1 分冊, pp.883-892, 2004.8

5）松岡祐一，ジェイソンマコーミック，吹田啓一郎，中島正愛 : 軽量鉄骨下 地間仕切り壁とそれに囲まれた鋼製下地天井の耐震性能, 日本建築学会構 造系論文集，第632号，pp.1857-1864，2008.10

6）小林俊夫，由利隆行，荒井智一：鋼製天井下地を用いた吊り天井の耐震性 に関寸る研究, 日本建築学会構造系論文集, 第630号, pp.1295-1302, 2008.8

7）渡壁守正，飯塚信一，ほか 4 名：大規模空間を有する在来工法天井の耐震 対策工法の開発，日本建築学会技術報告集，第18巻第39号，pp.465-470, 2012.6

8）西山功, 伊藤弘, 西田和生, 梁一承 : 在来工法天井及びシステム天井の動 的加振実験, その $1 \sim 2$, 日本建築学会大会学術講演梗概集, B-2分冊, pp.847-850, 2002.8

9） 中本康, 元結正次郎, ほか 3 名 : 鋼製下地在来工法天井におけるクリップ の力学的特性に関する研究, その $1 \sim 3$, 日本建築学会大会学術講演梗概集, B-1分冊, pp.843-848, 2006.9

10）杉山達也，貫井泰，ほか 9 名：在来工法天井の構成部材および実大天井の 力学的特性に関する実験研究, その $1 \sim 6$, 日本建築学会大会学術講演梗概 集，B-1分冊，pp.227-238，2009.8

11）杉山達也，貫井泰，ほか 10 名 : 在来工法天井の下地ボードと野縁のビス止め 接合部のせん断試験 その $1 \sim 3$, 日本建築学会大会学術講演梗概集, B-1 分冊, pp.871-876, 2010.9

12）船積宏彰, 元結正次郎, ほか5 名 : 在来工法による鋼製下地天井の力学的 特性に関寸る研究，その1２，日本建築学会大会学術講演梗概集，B-1分 冊, pp.911-914, 2005.9

13）船積宏彰, 元結正次郎, ほか 6 名：鋼製下地在来工法天井の動的性状 そ の $2 \sim 6$, 日本建築学会大会学術講演梗概集, B-1分冊, pp.877-886, 2009.8

14）永井拓生, 川口健一: 在来工法吊天井の面内剛性の評価と振動性状に及ぼ 寸影響について, 日本建築学会大会学術講演梗概集, B-1分冊, pp.883-884, 2010.9

15）鈴木健司，金子美香，他 3 名：鋼製下地在来工法天井の耐震性に関する実 験的研究，清水建設研究所報告，第89号，pp.23-28，2012.2

注

注 1 ) 部分補強された在来工法天井の静的繰り返し加力実験について

本論で述べた解析を行うため, 付図 1 , 付図 2 に示した $2 \mathrm{~m}^{2}$ 規模のブレ 一ス付き天井部分試験体に対して, 図中の加力治具の点に変位制御の水平 方向静的繰り返し加力実験を行い, 部分補強されたブレース・天井系の力 
学特性を把握した。天井ボードは 2 枚張りで, 補強方法は, 本文で述べた 試験体 A と同様である。載荷においては, 野縁受け方向ではブレースの座 屈と野縁の仕口の開き, 野縁方向では耐震クリップの滑動と野縁受けの曲 げ変形が見られ，これらは本論の動的実験の経過と同じである。

得られた外力と天井面水平変位による荷重変形関係を付図 3 に示す。こ の際，計測されたクリップ部分の変位（天井面一ブレース下端間の相対変 位）から, クリップ部の荷重変形関係を求めた。更に, 付図 4 に示寸 2 節 点モデルを構筑することを意図して付図 5 に示すようなブレースの静的加 力実験を別途実施した。試験体はブレースとブレースホルダーと吊りボル トから成り, 吊りボルトに張力を与えた状態で, ブレースに正負軸力を与 えた。得られたブレースの軸方向の荷重変形関係を付図 6 に示す。変形は ブレースホルダーの回転に拠るところが大きく, ブレース部分のトラスモ デルには, ブレースホルダー部分の剛性が含まれる。これらの力学特性を, 本論の第 3 節で述べた解析諸元でモデル化し, 実験結果と比較したものを 付図 7, 付図 8, 付図 9 に示寸。図中, $\mathrm{X}$ は野縁受け方向, $\mathrm{Y}$ の野縁方向で ある。また, 天井ユニット全体モデルの等価剛性および等価減衰定数を, 静的加力実験による值と比較して付図 10 に示す。ブレースの軸方向の特性 とクリップ部分の水平方向の特性とをモデル化して得られた全体の水平方 向の特性が，概放実験による荷重変形関係と整合していることが分かる。 なお, 等価剛性は最大 ・最小変位点割線剛性の平均値, 等価減衰定数は次 式による。

heq $=\Delta \mathrm{W} /(4 \pi \mathrm{We})$

ここに, heq : 等価減衰定数, $\Delta \mathrm{W}: 1$ 履歴ループの吸収エネルギー, We 最大・最小変位点割線剛性の弾性エネルギー平均值
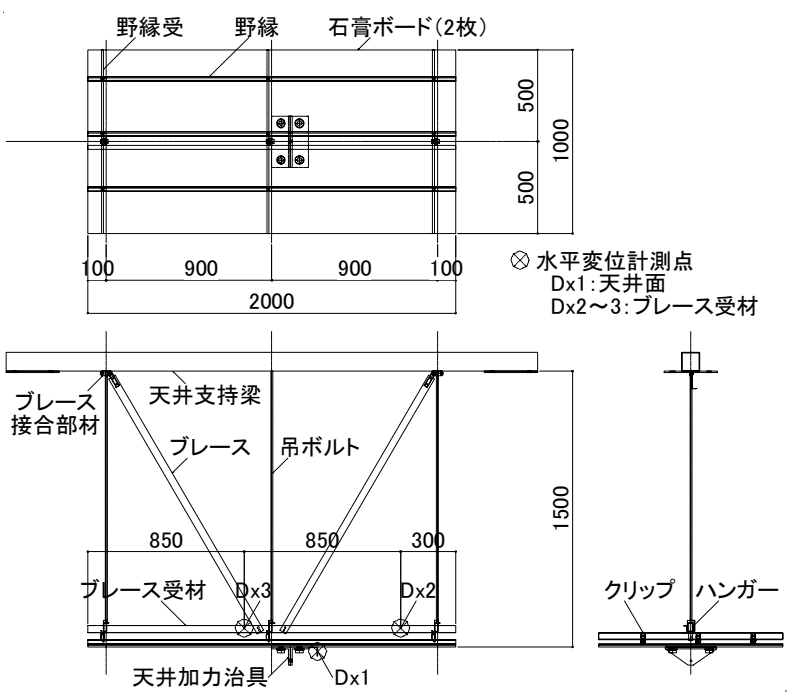

付図 $12 m^{2}$ 規模のブレース・天井試験体（野縁方向） 野縁＼cjkstart野線受＼cjkstart石膏ボード(2枚)
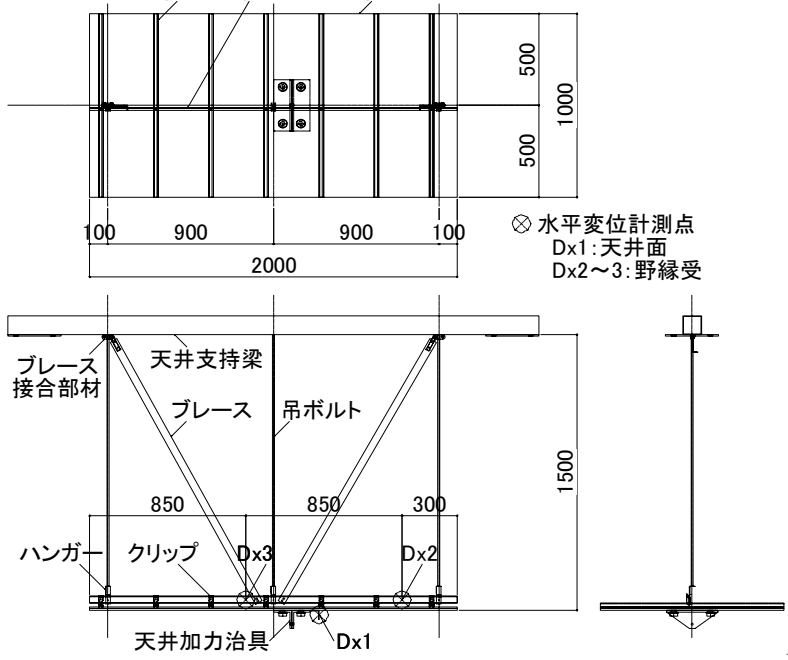

付図 $22 m^{2}$ 規模のブレース・天井試験体（野縁受け方向）
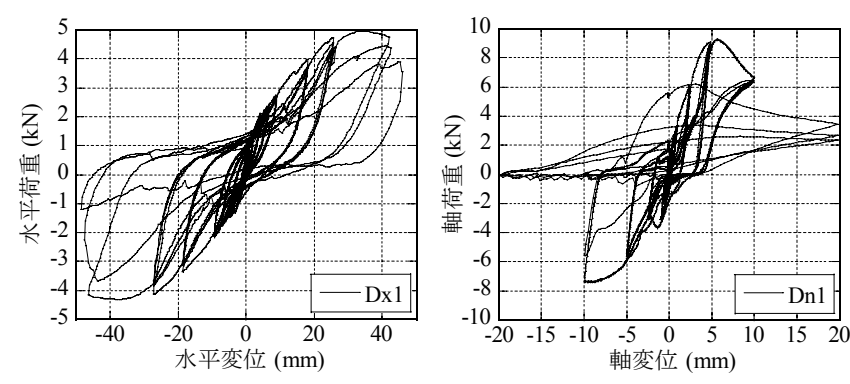

付図 3 荷重変形関係の例

付図 6 ブレース+ホルダーの実験結果

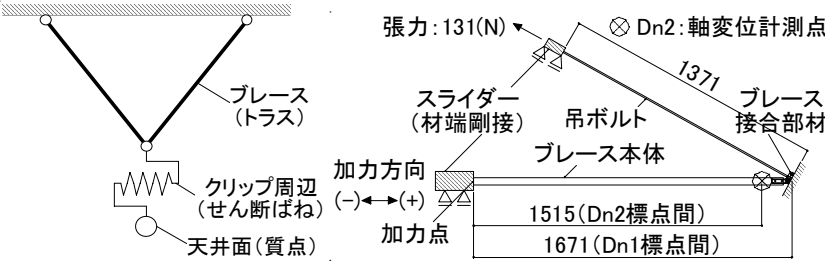

付図 4 2 節点モデル

付図 5 ブレース+ホルダーの実験
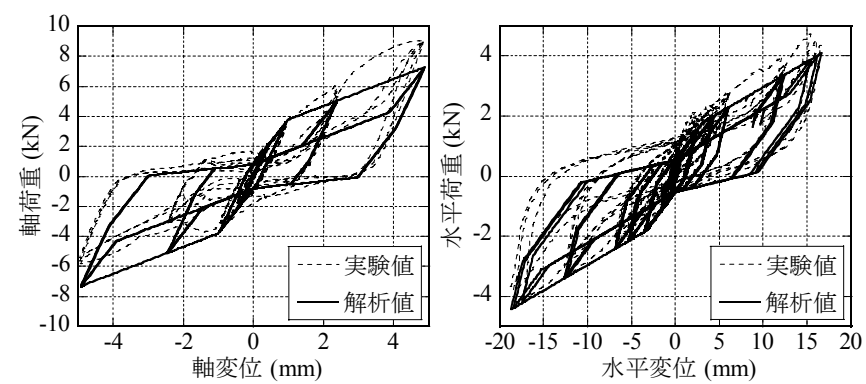

付図 7 ブレース部の荷重変形関係 付図 8 クリップ部の荷重変形関係
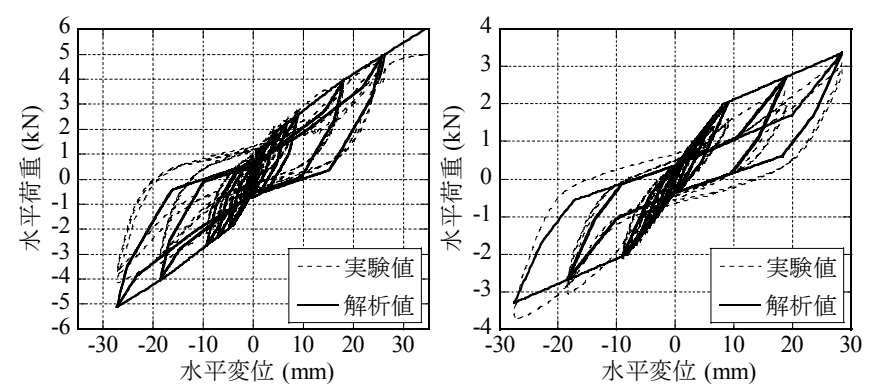

付図 9 全体の荷重変形関係（左：X 方向，右：Y 方向）
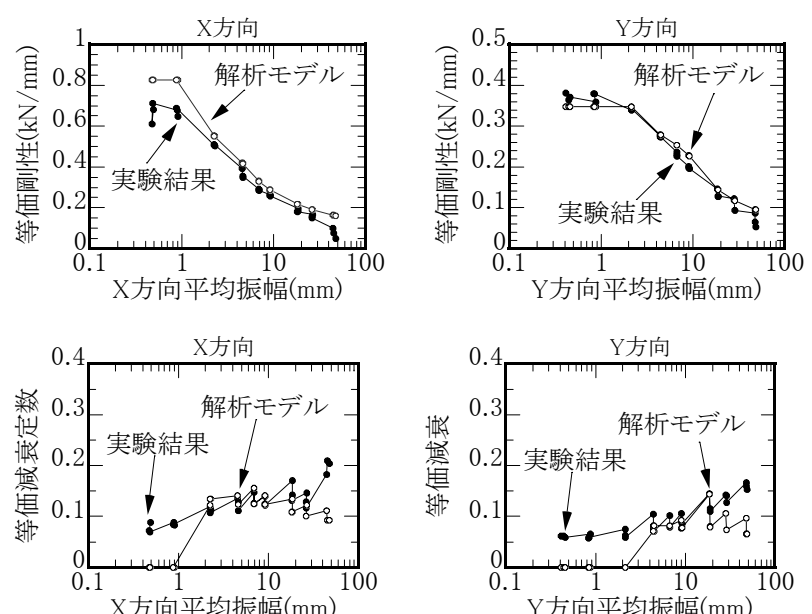

付図10 等価剛性・減衰定数のモデルと静的実験結果の比較 


\title{
Tetsuya HANZAWA*, Eiji TANAKA*, Kenji SUZUKI*, Fumihiko SAKURABA* and Mika KANEKO**
}

\author{
* Institute of Technology, Shimizu Corporation, M. Eng. \\ ** Institute of Technology, Shimizu Corporation, Dr. Eng.
}

\section{INTRODUCTION}

In recent years, the collapse of ceilings due to earthquakes has become a serious problem. The authors have proposed the reinforcing method to improve the aseismic performance of conventional ceilings. The proposed method employs the partial reinforcement only around the braces of ceilings. The shaking table tests of the partially reinforced ceilings were carried out to investigate dynamic characteristics. The analytical model of the reinforced ceilings is proposed based on the static cyclic loading tests and the simulation analyses were carried out to show the effectiveness of the analytical model.

\section{DYNAMIC TEST}

\subsection{Outline of the test}

Figures 1 and 2 show the specimens of the vibration test. The number of the specimens is two, and both of them are the partially reinforced ceiling. The specimen-B is further reinforced toward the specimen-A to prevent the steel clips from gliding along the ceiling joist.

2.2 Process of the test

Specimen-A in X direction: Compression buckling arose in the brace for El Centro $600 \mathrm{~cm} / \mathrm{sec}^{2}$.

Specimen-A in Y direction: The steel clips glided along the ceiling joist for El Centro $600 \mathrm{~cm} / \mathrm{sec}^{2}$.

Specimen-B in X direction: Compression buckling didn't arise in the brace for El Centro $600 \mathrm{~cm} / \mathrm{sec}^{2}$ because of increased thickness of the braces.

Specimen-B in Y direction: The steel clips didn't glide along the ceiling joist in response to El Centro $600 \mathrm{~cm} / \mathrm{sec}^{2}$.

2.3 The test results

Figures 5 and 6 show the amplitudes of the transfer functions of the specimens A and B based on the white noise inputs. The natural frequency in Y-direction of the specimens $\mathrm{A}$ and $\mathrm{B}$ is about $5 \mathrm{~Hz}$. The natural frequency in X-direction of the specimen $\mathrm{B}$ is about $4.4 \mathrm{~Hz}$, and though that of the specimen $\mathrm{A}$ is about $6 \mathrm{~Hz}$. The test with white noise of the specimen-B in X-direction was carried out after the tests with seismic wave in Y-direction, the natural frequency in X-direction is considered to be affected by the loading history in Y-direction. Tables 4 and 5 show the value of the maximum response acceleration and displacement of the specimens subjected to seismic waves.

\section{SIMULATION ANALYSES}

3.1 Analytical model

Figure 10 shows the analytical model of the specimen. The characteristics of the restoring force of the clips and the brace are based on the static cyclic tests (see NOTE-1). Figure 10 in NOTE-1 shows the equivalent stiffness and damping factor of the analytical model in compared with the test results. The calculated equivalent stiffness and damping factor are in good agreement with the experimental data.

3.2 Results of Simulation Analyses

Tables 8, 9 and Figure 17 show the calculated values of the maximum acceleration and displacement, and the ratios to the experimental data. Figures 13-16 show the response acceleration and displacement waves in compared with the experimental data. The calculated responses are in good agreement with the experimental data.

4. CONCLUSIONS

1) The natural frequencies of the reinforced ceiling based on the white noise tests are reasonably corresponding to the one base on the static cyclic loading tests.

2) The natural frequency of the reinforced ceiling is found to vary for small amplitudes of displacement. But the response for large amplitudes of displacement is not affected by the change of the natural frequency in range of the small amplitude.

3) The aseismic performance of specimen B in Y-direction improves in compared with that of specimen A.

4) The calculated response acceleration and displacement waves are in good agreement with the experimental data.

5) The accuracy of the simulation analyses of the reinforced ceiling subjected to the small input motions decreases after the large input motions. 